\title{
Owner Ethnicity: The Determinant of Relationship between Environment Uncertainty and Performance
}

\author{
Lussia Mariesti Andriany \\ STIE ASIA Malang \\ lussia.andriany@gmail.com
}

\begin{abstract}
The aim of this research is to reveal effect of environment uncertainty which seen through competition level and costumer to performance. This research reveals the difference of relationship in environment uncertainty to performance between Chinese and non-Chinese business. Data are collected through direct survey to traditional retail owners by questionnaire and interview. Then, those data analyze in two stages, confirmatory factor analysis and simple regression with dummy variable. This research finds that there is no effect from environment uncertainty to performance. Also, there is no difference between Chinese and non-Chinese business in environment uncertainty to performance relationship.
\end{abstract}

Keywords: ethnic of business ownership, environment uncertainty, performance

\begin{abstract}
Abstrak: Tujuan dari penelitian ini adalah pengungkapan pengaruh ketidakpastian lingkungan yang dilihat melalui kondisi tingkat persaingan dan konsumen pada kinerja. Penelitian ini juga mengungkapkan perbedaan hubungan tersebut berdasarkan etnis kepemilikan usaha, yaitu etnis Cina dan non-Cina. Data diambil menggunakan metode survei langsung dengan instrumen angket untuk selanjutnya dianalisis dalam dua tahap, yaitu análisis faktor konfirmatori dan análisis regresi sederhana dengan variabel dummy. Data juga dikumpulkan melalui wawancara pada beberapa responden penelitian, yaitu pemilik usaha, sebagai pengayaan data kuantitatif yang diperoleh dari angket.Hasil dari penelitian ini adalah tidak adanya pengaruh antara ketidakpasian lingkungan usaha dan kinerja usaha serta tidak terdapat perbedaan antara hubungan tersebut pada usaha yang dimilik etnis Cina dan non-Cina.
\end{abstract}

Kata kunci: Etnis kepemilikan usaha, Ketidakpastian lingkungan, Kinerja

Perubahan lingkungan yang cepat membawa dampak pada bagaimana sebuah organisasi mengelola dan memformulasikan strategi mereka (Hutabarat, 2006). Saat ini, strategi organisasi cenderung berubah menjadi lebih kompleks karena strategi diarahkan pada konsep yang fleksibel dan dinamis (D’Aveni dan Gunther, 1994). Salah satu lingkungan yang memengaruhi organisasi adalah lingkungan eksternal yang dipandang sebagai kondisi dinamis yang sulit diramalkan perubahannya, serta dapat menciptakan peluang dan tantangan bagi organisasi (Child, 1997; Swamidass dan Newel, 1987; Clarke, 1994) sehingga keberhasilan organisasi tergantung pada kemampuan memantau lingkungan eksternal mereka (Boyd dan Fulk, 1996). Kesulitan organisasi untuk meramalkan perubahan lingkungan eksternal terutama berhubungan dengan permintaan pasar dan tingkat persaingan (Suardhika, 2011) yang merupakan sumber ketidakpastian bagi organisasi (Miliken, 1987).

Pada beberapa penelitian terdahulu, tingkat ketidakpastian lingkungan eksternal organisasi akan berpengaruh terhadap kinerja organisasi. Wiklund (1999) menyatakan bahwa 
tingkat ketidakpastian lingkungan eksternal organisasi memengaruhi kinerja mereka tanpa melihat strategi yang dipilih organisasi. Temuan tersebut didukung oleh Nurhajati (2004) yang menyatakan lingkungan eksternal yang berhubungan dengan pembeli berpengaruh positif pada kinerja organisasi. Hal tersebut berlawanan dengan hasil penelitian Suardhika (2011) yang menyatakan bahwa peningkatan ketidakpastian lingkungan dan intensitas persaingan yang dihadapi organisasi mampu menghambat atau menurunkan kinerja mereka. Berbeda dengan ketiga penelitian tersebut, penelitian yang lain tidak menemukan hubungan antara kondisi lingkungan eksternal dengan kinerja organisasi (Pagell dan Krause, 2003) serta tidak menemukan hubungan langsung antara kedua variabel tersebut (Pelham, 1999; Rivard et al., 2005; Parnell et al., 2000).

Kontradiksi hasil penelitian tersebut memberikan peluang untuk penelitian lebih lanjut mengenai hubungan antara ketidakpastian lingkungan yang terwujud dalam tingkat persaingan dan perubahan permintaan pasar dengan kinerja organisasi. Pengungkapan kembali mengenai hubungan tersebut diperlukan pada konteks budaya tertentu sesuai dengan saran untuk penelitian mendatang dari Judge dan Douglas (2009). Suatu penelitian pada budaya yang berbeda berfungsi untuk memperluas pemahaman mengenai kemampuan adaptasi organisasi, di mana pada budaya yang berbeda kemampuan adaptasi pada lingkungan usaha juga akan berbeda (Trompenaars dan Wolliams, 2003).

Fenomena sehubungan dengan dinamisme lingkungan eksternal terjadi pada sektor ritel. Ritel yang merupakan aktivitas bisnis yang meliputi menjual barang dan jasa pada konsumen untuk kebutuhan pribadi, keluarga, atau rumah tangga antara penjual dan konsumen akhir dan dalam kuantitas yang kecil (Berman et al., 2006; Sugiarta, 2011) mengalami persaingan yang luar biasa. Persaingan tersebut terjadi karena perkembangan ritel modern yang begitu pesat. Data Bank Mandiri (Persero) pada Industry Update volume 16 tahun 2014 menyatakan bahwa potensi pasar ritel Indonesia untuk jangka menengah dan panjang masih besar dan didominasi oleh ritel modern format minimarket, convenience store, dan hypermarket (Bank Mandiri, 2014). Pesatnya pertumbuhan sektor ritel modern tentunya akan mendesak ritel tradisional. Saddewisasi et al. (2011) dan Suman (2011) menyebutkan bahwa peningkatan jumlah ritel modern menyebabkan penurunan omset penjualan, perputaran barang, dan laba kotor dari ritel tradisional.

Berdasarkan penjelasan sebelumnya, maka peneliti tertarik untuk mengkaji kembali hubungan antara ketidakpastian lingkungan dengan kinerja pada ritel tradisional sebagai pihak yang terimbas perkembangan pesat ritel modern. Akibat perkembangan pesat tersebut, 
lingkungan eksternal ritel modern akan semakin dinamis dan tidak pasti. Selain itu, peneliti juga menambahkan faktor budaya sebagai pembeda hubungan tersebut. Pada penelitian ini, faktor budaya tercermin pada perbedaan etnis kepemilikan ritel tradisional. Peneliti menjadikan etnis Cina sebagai dasar perbedaan etnis kepemilikan usaha karena berbagai alasan. Pertama, etnis Cina sangat mendominasi sektor ekonomi Indonesia dan dipandang sebagai usaha yang dinamis (Jaya, 2012; Rahayu, 2005). Kedua, etnis Cina juga menguasai sebagian besar jalur perdagangan, mulai hulu hingga hilir (Putri, 2015). Tulisan ini akan terbagi menjadi beberapa bagian, yaitu pendahuluan, kajian teori dan literatur, metode penelitian, hasil dan pembahasan, serta kesimpulan penelitian.

\section{Ketidakpastian Lingkungan}

Ketidakpastian lingkungan adalah kondisi pada saat organisasi tidak dapat memprediksi lingkungan eksternal mereka dengan akurat (Miliken, 1987). Ketidakpastian lingkungan akan berdampak pada operasional sebuah organisasi dengan cara menciptakan tantangan dan hambatan (Child, 1997; Swamidass dan Newel, 1987; Clarke, 1994). Kemampuan pihak manajemen untuk memprediksi lingkungan eksternal mereka menjadi salah satu yang menentukan keberhasilan organisasi (Boyd dan Fulk, 1996). Sumber dari ketidakpastian lingkungan adalah persaingan dari organisasi yang bergerak di bidang yang sama dan selera konsumen yang mengalami perubahan (Rivard et al., 2005). Kedua sumber ketidakpastian lingkungan tersebut membuat organisasi harus mencari jalan untuk dapat bertahan dan menang dalam persaingan pasar (Rivard, et al., 2005).

\section{Kinerja}

Penilaian kinerja memiliki nilai penting bagi organisasi, karena selain digunakan sebagai ukuran keberhasilan dalam periode tertentu, dapat juga dijadikan masukan untuk perbaikan atau peningkatan kinerja organisasi di masa yang akan datang. Secara umum, konsepsi kinerja organisasi didasarkan pada gagasan bahwa perusahaan merupakan sekumpulan aset produktif, yang meliputi sumber daya manusia, sumber daya fisik, dan modal untuk mencapai tujuan bersama (Carton dan Hofer, 2006). Kinerja usaha selain cerminan keberhasilan atau kegagalan dari suatu organisasi, juga dapat menggambarkan hasil yang dicapai organisasi dari serangkaian pelaksanaan fungsi kerja atau aktivitas dalam periode tertentu (Wheelen dan Hunger, 2011). Dalam penelitian yang mengambil objek usaha kecil dan menengah, penilaian kinerja dilakukan dengan menggunakan pendekatan finansial 
dan non-finansial untuk mengukur sejauh mana sebuah usaha mencapai tujuannya (Chong, 2008) karena penilaian kinerja secara komprehensif akan menghasilkan informasi menyeluruh mengenai kinerja organisasi (Parnell et al., 2000). Pada penelitian ini kinerja organisasi diukur melalui aspek profitabilitas sebagai cerminan dari pendekatan finansial dan aspek pasar sebagai cerminan dari pendekatan non-finansial (Sanchez dan Marin, 2005).

\section{METODE}

\section{Objek dan Lokasi Penelitian}

Organisasi atau usaha yang dipilih sebagai objek pada penelitian ini adalah ritel tradisional. Objek tersebut dipilih karena beberapa pertimbangan, yaitu sebagai usaha yang terkena imbas perkembangan pesat ritel tradisional sehingga lingkungan eksternal mereka menjadi semakin dinamis dan tidak pasti. Penelitian dilakukan pada usaha ritel tradisional yang berada di sekitar ritel modern, yaitu Alfamart atau Indomaret di Kota Malang. Penentuan lokasi penelitian didasarkan pada adanya ketidakseimbangan persaingan yang terjadi antara ritel modern dan tradisional sehingga posisi tawar dari ritel tradisional menurun (Suman, 2011).

Ritel tradisional yang dipilih berjarak maksimal 500 meter dari ritel modern yaitu Alfamart atau Indomaret. Syarat ini ditetapkan dengan mengingat adanya Peraturan Daerah No. 8 Tahun 2010 yang menyatakan bahwa pendirian toko modern hanya boleh dilakukan pada jarak 500 meter antar toko modern dan toko tradisional. Namun pada kenyataannya, pendirian toko modern sering dilakukan tidak dengan mengindahkan peraturan tersebut, sehingga dalam penelitian ini toko tradisional yang berada pada jarak kurang dari 500 meter dari toko modern dipandang sebagai ritel tradisional yang terdampak oleh keberadaan ritelmodern. Ritel tradisional yang terdapat di sekitar ritel modern merupakan ritel milik etnis Cina dan non-Cina. Syarat ini ditetapkan berdasarkan tujuan penelitian yaitu mengetahui adanya perbedaan hubungan ketidakpastian lingkungan dengan kinerja antara ritel tradisional milik etnis Cina dan non-Cina di Kota Malang.

\section{Variabel Penelitian}

Variabel yang digunakan dalam penelitian ini diringkas dalam Tabel 1.

Tabel 1. Variabel Penelitian

\begin{tabular}{clll}
\hline NO & \multicolumn{1}{c}{ VARIABEL } & \multicolumn{1}{c}{ INDIKATOR } & \multicolumn{1}{c}{ SUMBER } \\
\hline $\mathbf{1}$ & Ketidakpastian & Tingkat persaingan & Rivard et. al. (2005) dan \\
& lingkungan & $\begin{array}{l}\text { Perubahan selera } \\
\text { konsumen }\end{array}$ & Khandwalla (1977) \\
& & & \\
\hline
\end{tabular}




\begin{tabular}{llll}
\hline $\mathbf{2}$ & Kinerja & Profitabilitas & Chong (2008); Sanchez \\
& & Penjualan & dan Marin (2005) \\
$\mathbf{3}$ & \multirow{2}{*}{ Etnis Kepemilikan Usaha } & $\begin{array}{l}\text { Ritel milik etnis Cina } \\
\text { dummy }=1\end{array}$ \\
& & Ritel milik etnis non-Cina & dummy =0 \\
\hline
\end{tabular}

Sumber: data diolah (2016)

\section{Model Penelitian}

Model pada penelitian ini dapat dilihat pada Gambar 1 berikut ini.

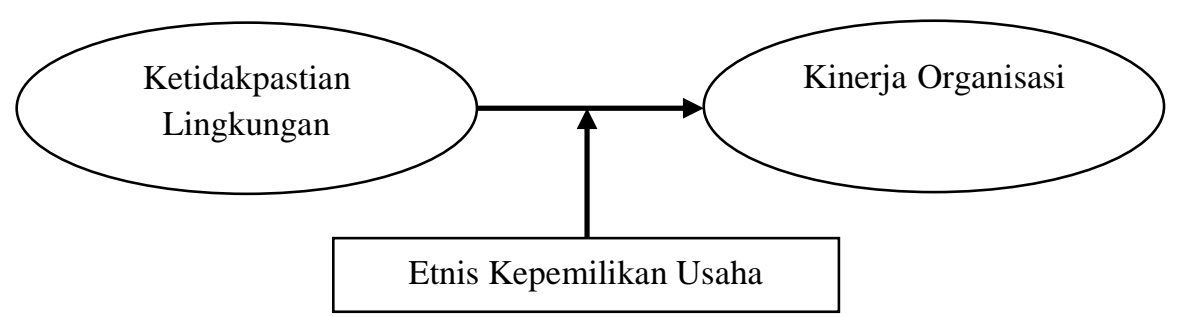

Gambar 1. Model Penelitian

\section{Teknik Pengumpulan dan Analisis Data}

Metode pengumpulan data pada penelitian ini adalah dengan metode survei langsung dengan instrumen angket atau daftar pernyataan kepada responden penelitian, yaitu pemilik ritel. Peneliti memberikan angket secara langsung kepada pemilik karena pemilik merupakan pihak yang paling mengerti bagaimana strategi organisasi dalam menghadapi persaingan serta pihak yang bertanggung jawab untuk mempertahankan kelangsungan hidup organisasi. Selain memberikan angket kepada responden penelitian, peneliti juga melakukan wawancara kepada beberapa pemilik ritel tradisional, baik pemilik dari etnis Cina maupun dengan etnis nonCina. Wawancara dilakukan untuk menggali informasi dari pemilik sehubungan dengan tanggapan mereka terhadap perubahan kondisi lingkungan usaha yang terjadi, sekaligus sebagai pengayaan data kuantitatif yang diperoleh dari hasil angket.

Instrumen penelitian diuji validitas dan reliabilitasnya. Uji validitas dilakukan menggunakan korelasi bivariate pearson product momento dan dikatakan valid apabila nilai koefisien signifikan pada tingkat $1 \%$ atau 5\% (Ghozali, 2011). Uji reliabilitas dilakukan dengan melihat nilai Cronbach Alpha $(\alpha)$ di atas 0.60 (Nunnally, 1978 dalam Chew et al., 2008). Berdasarkan hasil uji validitas dan reliabilitas, semua ítem pernyataan pada kuisioner dinyatakan valid dan reliabel.

Setelah data terkumpul, análisis dilakukan 2 tahap, yaitu análisis faktor konfirmatori untuk mengetahui skor faktor tiap variabel dan regresi sederhana dengan variabel dummy. Penggunaan analisis regresi sederhana dengan variabel dummy didasarkan pada alasan bahwa 
regresi berganda yang dilengkapi dengan variabel dummy membuat model regresi menjadi alat yang fleksibel dan mampu menyelesaikan banyak permasalahan menarik dalam penelitian empiris (Gujarati, 1995). Fleksibilitas tersebut didapat karena dalam model regresi berganda variabel bebas tidak hanya dipengaruhi oleh variabel yang dapat langsung dikuantifikasikan, tetapi terkadang juga dipengaruhi oleh variabel yang tidak dapat dikuantifikasikan (Gujarati, 1995). Penjelasan tersebut sesuai dengan model penelitian di mana variabel terikat yaitu kinerja organisasi dipengaruhi oleh variabel ketidakpastian lingkungan yang dapat dikuantifikasi melalui skala likert 5 poin, serta variabel kualitatif yang tidak dapat dikuantifikasi, yaitu etnis kepemilikan usaha. Dengan digunakan variabel dummy, maka dapat diketahui adanya perbedaan hubungan ketidakpastian lingkungan dan kinerja antara ritel tradisional milik etnis Cina dan non-Cina.

\section{HASIL dan PEMBAHASAN}

\section{HASIL}

\section{Ketidakpastian Lingkungan}

Pada Tabel 2 di bawah ini ditampilkan profil variabel ketidakpastian lingkungan.

Tabel 2. Profil Variabel Ketidakpastian Lingkungan

\begin{tabular}{cccc}
\hline Indikator & \multicolumn{2}{c}{ Bobot faktor } & \multirow{2}{*}{ Rerata (Mean) } \\
\cline { 2 - 3 } Tingkat persaingan dengan ritel modern & Koefisien & sig & \\
Perubahan selera konsumen & 0.757 & 0.386 & $\mathbf{3 . 6 8}$ \\
\hline
\end{tabular}

Sumber: data diolah (2016)

Hasil kajian dalam Tabel 2 menunjukkan bahwa tingkat persaingan dengan ritel modern dan perubahan selera konsumen tidak terkonfimasi sebagai indikator yang membuat ritel tradisional tidak mampu melihat kondisi lingkungan eksternal mereka. Hal tersebut diketahui dari nilai signifikansi skor faktor lebih dari 0.05. Hasil ini berarti tidak mendukung konsep ketidakpastian lingkungan yang diungkapkan oleh Rivard et al. (2005) dan Khadwalla (1977).

Kondisi seperti dalam Tabel 2 menunjukkan bahwa tingkat persaingan dengan ritel modern sekaligus perubahan selera konsumen sebenarnya tidak membuat lingkungan eksternal organisasi menjadi tidak dapat diprediksi. Hasil tersebut disebabkan oleh kemampuan ritel tradisional untuk menyesuaikan diri dengan kondisi lingkungan yang dihadapi. Selain itu, ritel tradisional juga memanfaatkan promo yang dilakukan oleh ritel modern untuk menyesuaikan jenis produk yang dijual dan mengetahui harga terbaru dari 
produk tersebut. Pemanfaatan tersebut membuat ritel tradisional mampu memprediksi selera konsumen, sehingga keusangan produk yang dijual oleh ritel tradisional juga dapat dihindari. Berdasarkan hal tersebut, maka ritel tradisional sebenarnya sudah mampu memprediksi lingkungan eksternal mereka walaupun pemilik ritel tersebut menganggap tingkat persaingan dengan ritel modern dan perubahan selera konsumen merupakan sumber ketidakpastian lingkungan yang akan membuat ritel tradisional kesulitan untuk bertahan dalam kondisi lingkungan yang terus berubah.

\section{Kinerja}

Tabel 3 di bawah ini menunjukkan hasil analisis konfirmatori dari variabel kinerja.

Tabel 3. Profil Variabel Kinerja

\begin{tabular}{lccc}
\hline \multirow{2}{*}{ Indikator } & \multicolumn{2}{c}{ Bobot faktor } & Rerata (Mean) \\
\cline { 2 - 3 } & Koefisien & sig & \\
Profitabilitas & 0.924 & 0.000 & $\mathbf{3 . 6 3}$ \\
Penjualan & 0.924 & 0.000 & 3.58 \\
\hline
\end{tabular}

Sumber: data diolah (2016)

Hasil kajian pada Tabel 3 menunjukkan bahwa profitabilitas dan pasar terkonfirmasi sebagai aktivitas finansial dan non-finansial yang membentuk kinerja organisasi. Hal tersebut dibuktikan dari semua skor faktor dari indikator kinerja memiliki nilai signifikansi kurang dari 0.05. Temuan ini memperkuat model pengukuran milik Chong (2008) serta Sanchez dan Marin (2005).

Informasi lain yang dapat digali pada Tabel 3 di atas adalah skor faktor dari kedua indikator kinerja organisasi sama, yaitu sebesar 0.924. Kondisi ini menunjukkan bahwa secara konseptual profitabilitas dan penjualan merupakan ukuran yang penting dalam pencapaian kinerja organisasi karena peningkatan keuntungan dan modal usaha akan membuat pasar ritel tradisional meningkat, sebaliknya peningkatan penjualan dan jumlah konsumen akan meningkatkan keuntungan dan membuka kesempatan bagi pemilik ritel untuk menambah modal usaha. Namun demikian, pemilik ritel tradisional memandang bahwa pencapaian profitabilitas yang tinggi merupakan ukuran terkuat dari pencapaian kinerja yang terlihat dari skor rerata yang lebih tinggi dibanding indikator pasar. Hal ini berarti pemilik ritel tradisional memfokuskan usaha mereka untuk meningkatkan keuntungan dan menambah modal usaha dibanding memperluas pasar dengan cara berusaha meningkatkan jumlah konsumen dan jumlah penjualan melalui peningkatan jumlah serta ragam produk yang dijual. 
Dengan demikian, hasil temuan ini memberikan indikasi bahwa kedua indikator yang berperan dalam membentuk kinerja organisasi, belum sepenuhnya dicapai oleh ritel tradisional. Temuan ini sesuai dengan kenyataan yang ada bahwa pemilik ritel tradisional cenderung mempertahankan konsumen mereka karena keengganan pemilik untuk merebut konsumen ritel yang lain. Hal itu terjadi karena pemilik ritel tradisional menganggap dengan merebut konsumen ritel lain, berarti mereka telah melakukan persaingan yang tidak sehat.

\section{Hasil Uji Hipotesis}

Pada Tabel 4 di bawah ini ditunjukkan hasil pengujian hipotesis penelitian.

Tabel 4. Hasil Uji Hipotesis Penelitian

\begin{tabular}{clccc}
\hline Notasi & \multicolumn{1}{c}{ Hubungan Variabel } & \multicolumn{2}{c}{ Uji Hipotesis } & Keputusan \\
\cline { 3 - 4 } & & t-hitung & Sig. & \\
H1 & Ketidakpastian Lingkungan $\rightarrow$ Kinerja & 0.444 & 0.660 & ditolak \\
H2 & Etnis Kepemilikan Usaha $\rightarrow$ Ketidakpastian & 0.789 & 0.436 & ditolak \\
\hline
\end{tabular}

Sumber: data diolah (2016)

Berdasarkan Tabel 4 diperoleh nilai t-hitung dan signifikansi yang dapat dijabarkan sebagai berikut:

\section{H1: Ketidakpastian lingkungan berpengaruh pada kinerja}

Informasi pada Tabel 4 menyatakan bahwa nilai t-hitung sebesar 0.444 dan signifikansi 0.660 (> 0.05). Hal tersebut berarti hipotesis ditolak atau ketidakpastian lingkungan bukan variabel yang memengaruhi kinerja usaha.

\section{H2: Kinerja berbeda antara ritel trandisional kepemilikan etnis Cina dan non-Cina}

Informasi yang didapat dari Tabel 4 untuk hubungan etnis kepemilikan usaha dan ketidakpastian lingkungan adalah nilai t-hitung sebesar 0.789 dan signifikansi sebesar 0.436. Hasil tersebut mengindikasikan bahwa etnis kepemilikan usaha bukan merupakan variabel yang membedakan cara pandang ritel tradisional terhadap lingkungan eksternal mereka karena nilai signifikansi yang lebih dari 0.05. Dengan demikian, hipotesis kedua penelitian ini ditolak. 


\section{PEMBAHASAN}

\section{Pengaruh Ketidakpastian Lingkungan terhadap Kinerja}

Hasil penelitian untuk pengaruh ketidakpastian lingkungan terhadap kinerja organisasi menyatakan hasil yang tidak signifikan. Hasil ini memberikan makna bahwa ketidakpastian lingkungan yang bersumber dari tingkat persaingan dan perubahan selera konsumen bukan merupakan faktor yang membuat kinerja ritel tradisional menurun. Temuan ini merupakan temuan yang menarik karena ritel tradisional di Kota Malang mampu menghasilkan kinerja yang baik pada lingkungan yang terus berubah dan sesuai dengan pernyataan Boyd dan Fulk (1996) bahwa keberhasilan organisasi tergantung pada kemampuan mereka untuk memantau lingkungan eksternal mereka.

Temuan penelitian ini mendukung penelitian Pagell dan Krause (2003). Sebaliknya penelitian ini menolak hasil penelitian Suardhika (2011) dan Nurhajati (2004). Dalam penelitian Pagell dan Krause (2003) dinyatakan bahwa kondisi lingkungan eksternal tidak berhubungan dengan kinerja perusahaan manufaktur di Amerika Serikat. Sedangkan hasil penelitian Suardhika (2011) menyatakan bahwa ketidakpastian lingkungan yang merupakan bagian dari dinamika lingkungan usaha akan menurunkan kinerja UKM di Bali. Berbeda dengan kedua penelitian tersebut, Nurhajati (2004) menyatakan bahwa lingkungan eksternal usaha yang berhubungan dengan pembeli akan berpengaruh terhadap kinerja UKM di Jawa Timur.

Hasil penelitian ini mengindikasikan bahwa ritel tradisional di Kota Malang telah mampu mengatasi ketidakpastian lingkungan eksternal dengan memanfaatkan kemampuan manajerial dan organisasional mereka. Pemanfaatan tersebut sesuai dengan kenyataan bahwa pemilik ritel tradisional selalu berusaha untuk mendapat informasi mengenai produk baru dan harga terbaru dari produk yang dijual. Informasi tersebut didapat melalui beberapa cara, yaitu melalui media elektronik, melalui salesman yang datang ke toko atau pemasok usaha, dan melalui pemanfaatan promo yang dilakukan oleh ritel modern. Dengan beberapa cara tersebut, ritel tradisional mampu mengetahui produk baru yang diluncurkan di pasaran sehingga berdampak pada kinerja mereka. Pemaparan mengenai hasil pengujian hipotesis sesuai dengan pernyataan Rivard et al. (2005) yang menyatakan bahwa peningkatan ketidakpastian lingkungan usaha membuat usaha kecil selalu mencari cara dan memanfaatkan setiap kesempatan yang ada secara terus-menerus sehingga hal tersebut akan berdampak pada kinerja usaha mereka. 


\section{Pengaruh Perbedaan Etnis Kepemilikan Usaha pada Hubungan Ketidakpastian}

\section{Lingkungan dan Kinerja}

Hasil penelitian mengenai perbedaan budaya yang tercermin dalam perbedaan kepemilikan ritel tradisional akan berdampak pada hubungan ketidakpastian lingkungan dan kinerja organisasi mengungkapkan hasil yang tidak signifikan. Dengan hasil tersebut, maka perbedaan budaya bukan merupakan variabel yang memoderasi hubungan antara ketidakpastian lingkungan dan kinerja organisasi sesuai dengan pernyataan Harzig dan Hofstede (1996) bahwa perbedaan budaya akan berdampak pada tingkat pencegahan mereka terhadap perubahan.

Hasil penelitian ini sesuai dengan kenyataan bahwa pemilik ritel tradisional Cina dan non Cina sama-sama mampu memprediksi lingkungan eksternal mereka. Temuan penelitian sesuai dengan paparan dalam profil variabel ketidakpastian lingkungan yang mengungkapkan bahwa meskipun pemilik ritel tradisional secara umum menganggap ketidakpastian lingkungan sebagai hal yang tidak mampu mereka prediksi, tetapi usaha yang mereka lakukan untuk bertahan serta kemampuan manajerial dan organisasional yang mereka miliki telah membuat lingkungan eksternal dapat diprediksi dan tidak berdampak pada kinerja organisasi. Selain itu, waktu penelitian berjarak lebih dari 10 tahun dari awal maraknya pendirian ritel modern yang berdampak pada hubungan perbedaan budaya dengan ketidakpastian lingkungan dan kinerja. Dalam kurun waktu lebih dari 10 tahun, ritel tradisional milik kedua etnis telah mencari cara untuk bertahan dalam persaingan dengan memanfaatkan kemampuan manajerial dan organisasional mereka sesuai dengan pernyataan Rivard et. al. (2005). Dengan demikian, perbedaan budaya memang tidak membedakan hubungan ketidakpastian lingkungan eksternal ritel tradisional dan kinerja organisasi.

\section{SIMPULAN}

Berdasarkan paparan hasil penelitian maka dapat ditarik kesimpulan bahwa ketidakpastian lingkungan tidak memengaruhi kinerja usaha. Selain itu, etnis kepemilikan usaha juga tidak berdampak pada hubungan antara ketidakpastian lingkungan dan kinerja. Hal tersebut disebabkan adanya kemampuan dan fleksibilitas dari ritel tradisional untuk menggunakan kemampuan mereka dalam mengatasi ketidakpastian lingkungan yang terjadi. Penelitian ini memiliki beberapa keterbatasan yang menjadi peluang untuk peneliti selanjutnya. Pertama, kondisi persaingan pada penelitian ini spesifik sehingga kemampuan generalisasi hasil penelitian menjadi lebih terbatas. Peneliti selanjutnya dapat 
mempertimbangkan untuk kondisi persaingan yang berbeda untuk meningkatkan kemampuan generalisasi hasil penelitian. Kedua, penelitian ini melihat pada kondisi kinerja yang terbatas sehingga peneliti selanjutnya dapat melihat perkembangan usaha sejak awal didirikan dan melakukan pengayaan pengukuran kinerja dengan informasi kualitatif.

\section{DAFTAR RUJUKAN}

Bank Mandiri. (2014). Industry Update, September 2014, Volume 16. Jakarta: PT Bank Mandiri (Persero).

Berman, E., Hiltz, M. (2006). Retail Management: A Strategic Approach. Canadian Edition. Pearson Canada, Inc. Canada.

Boyd, B.K. and Fulk, J. (1996). Executive Scanning and Perceived Uncertainty: A Multidimentional Model. Journal of Management. Vol. 22, pp. 1-21.

Chew, D.A.S., Yan, S., Cheah, C.Y.J. (2008). Core Capability and Competitive Strategy for Construction SMEs in China. Chinese Management Studies. Vol.2, Iss: 3, pp. 203214.

Child, J. (1997). Strategic Choice in the Analysis of Action, Structure, Organization, and Environment: Retrospect and Prospect. Organization Studies. Vol. 18.

Chong, H. G. (2008). Measuring Performance of Small and Medium Sized Entreprises: The Grounded Theory Approach. Journal of Business and Public Affairs. ISSN 19347219, Vol. 2, Issue: 1.

Clarke, L. (1994). The Essence of Change, First Edition. Prentice Hall International, Ltd. UK.

D’Aveni, R.A. and Gunther, R. (1994). Hypercompetition; Managing the Dynamics of Strategic Maneuvering. The Free Press. New York, USA.

Ghozali, I. (2011). Aplikasi Analisis Multivariate dengan Program IBM SPSS 19. Badan Penerbitan Universitas Diponegoro. Semarang: Indonesia.

Gujarati, D.N. 1995. Basic Econometrics. McGraw Hill. New York, USA.

Harzig, A. and Hofstede, G. H. (1996). Planned Change in Organizations: The Influence of National Cultures. Research in the Sociology and Organizations: Cross Cultural Analysis of Organizations. JAI Press, pp. 297 - 340.

Hutabarat, J. dan Huseini, M. (2006). Pengantar Manajemen Strategik Kontemporer: Strategik di Tengah Operasional. PT Elex Media Komputindo. Jakarta, Indonesia.

Jaya, R.S. (2012). Dominasi Etnis Cina dalam Kegiatan Ekonomi di Indonesia Periode Tahun 1930 sampai Tahun 2000 [www] historyrendhy.blogspot.com. Tersedia pada: historyrendhy.blogspot.com/2012/06/dominasi-etnis-cina-dalam-kegiatan.html [Diakses pada: April 2015]

Judge, W. Q. and Douglas, T. (2009). Organizational Change Capacity: The Systematic Development of a Scale. Journal of Organizational Change Management. Vol. 22, No. 6, pp. 635 - 649.

Khandwalla, P.N. (1977). The Design of Organizations. Harcourt Brace Jovanovich. New York, USA.

Miliken, F. J. (1987). Three Types of Perceived Uncertainty about the Environment: State, Effect, and Response Uncertainty. Academy of Management Review. 1987. Vol. 12 No.1, pp.133-143.

Nurhajati. (2004). Analisis Faktor-Faktor yang Mempengaruhi Kinerja dan Keunggulan Bersaing Usaha Kecil yang Berorientasi Expor di Jawa Timur. Disertasi. Program 
Doktor Ilmu Ekonomi, Kekhususan Manajemen. Program Pascasarjana Fakultas Ekonomi dan Bisnis Universitas Brawijaya.

Parnel, J. A., Donald L. L., and Michael L. M. (2000). Strategy as A Response to Organizational Uncertainty: An Alternative Perspective on the StrategyPerformance Relationship. Management Decision. Vol. 38, Iss: 8, pp. 520 - 530.

Pagell, M. and Krause, D. R. (2003). Re-exploring the Relationship Between Flexibility and the External Environment. Journal of Operations Management. pp. 1 - 44.

Pelham. (1999). Influence of Environment, Strategy, and Market Orientation on Performance in Small Manufacturing Firms. Journal of Business Research. Vol. 45, pp. 33-46.

Putri, V. (2015). Etnis Cina dalam Perdagangan di Indonesia [www] academia.edu. Tersedia pada: https://www.academia.edu/5135355/ Etnis_cina_dlm_ perdagangan_di_indonesia [Diakses pada: April 2015]

Rahayu, M. (2005). Pembelajaran Organisasi sebagai Model Proses Manajemen Strategik pada Usaha Kecil Etnis Tiongwha dalam Industri Roti/Kue di Kota Malang. Disertasi. Program Doktor Ilmu Ekonomi, Kekhususan Manajemen, Program Pascasarjana Fakultas Ekonomi dan Bisnis, Universitas Brawijaya.

Rivard, S., Raymond, L., and Verreauld, D. (2005). Resource Based View and Competitive Strategy: an Integrated Model of Contribution of Information Technology. Journal of Strategic Information System. Vol. 14, pp. 29-50.

Saddewisasi, W., Ariefiantoro, T., dan Santoso, A. (2011). Analisis Dampak Usaha Ritel Modern terhadapa Usaha Retail Tradisional (Studi Kasus di Wilayah Kecamatan Gunungpati, Mijen, Tembalang, dan Banyumanik). Riptek. Vol. 5 No. 1, hal. 31-43.

Sanchez, A.A. and Marin, G.S. (2005). Strategic Orientation, Management Characteristics, and Performance: A Study of Spanish SME's. Journal of Small Business Management. Vol.43, No. 3, pp. 287-306.

Suardhika, I.N. (2011). Integrasi Sumber Daya Strategis, Orientasi Kewirausahaan, dan Dinamika Lingkungan sebagai Basis Strategi Bersaing serta Pengaruhnya terhadap Kinerja Usaha. Program Doktor Ilmu Manajemen Program Pascasarjana Fakultas Ekonomi dan Bisnis, Universitas Brawijaya.

Sugiarta, I. N. (2011). Panduan Praktis dan Strategis Retail Consumer Goods. Cetakan Pertama. Mizan Media Utama. Bandung, Indonesia.

Suman, A. (2011). Ritel Asing vs Pasar Tradisional [www] feb.ub.ac.id/. Tersedia pada: http://www.feb.ub.ac.id/agus-suman-ritel-asing-pasar-tradisional.html[Diakses pada: April 2015].

Swamidass, P. M. and Newell, W. T. (1987). Manufacturing Strategy Environment Uncertainty and Performance: A Path Analitic Model. Management Science. Vol. 33, No. 4, pp. 509-525.

Trompenaars, F. and Wolliams, P. (2003). A New Framework For Managing Change Across Culture. Journal of Change Management. Vol 3, Iss: 4, pp. 361 - 375.

Wiklund. (1999). The Sustainability of the Entreprenurial Orientation-Performance Relationship. Entrepreneurship Theory and Practice, Baylor University. 